\title{
The implementation of Audio Visual Media in improving students'vocabulary mastery through WhatsApp
}

\author{
Adelia Puspita $^{1}$, Cucu Sutarsyah ${ }^{2}$, Burhanuddin $^{3}$ \\ Universitas Lampung, Jl. Prof. Dr. SumantriBrojonegoro, Rajabasa, Bandar Lampung ${ }^{1,2,3}$ \\ 1adeliapuspita1400@gmail.com
}

\begin{abstract}
This quantitative research was conducted to investigate the students' vocabulary mastery after the implementation of audiovisual media through WhatsApp. The sample was 33 students from X MIPA 1 at SMA Muhammadiyah Bandar Lampung. This research based on the experimental group design which applied the pre-test and post-test as the instrument. Besides, the three meetings were conducted for the treatment. The data were analyzed by using Repeated Measured T-Test. The result of this research shows the mean score for the pre-test is 5.24. Meanwhile, the mean score for the post-test is 6.67. It means that the significant difference of students' vocabulary achievement reaches out the score of 1.43 points. More specifically, the tvalue $>\mathrm{t}$-table shows the number of 5.452 which is higher than the t-table 2.0369. Moreover, the value of significant 2-tailed is 0.000 which can be inferred that it is lower than 0.05 . Briefly, it can be inferred that the $\mathrm{H}_{1}$ is accepted and $\mathrm{H}_{0}$ is rejected.
\end{abstract}

Keywords:Audio Visual Media, Vocabulary, WhatsApp, Narrative Text.

\section{INTRODUCTION}

Language holds an essential role of communication in this world. This is reasonable because language as a tool of communication allows its user to convey what is in their mind to be delivered to anyone else. Moreover, in order to communicate one to another in daily life, people surely use language to share their ideas and purpose. Besides, it is possible for people to have a different language as another people due to the difference of national language that they have. Hence, the understanding of the language spoken and written of someone is needed in order to catch a clear meaning of their intention. For this reason, language can be considered as a main point to build up the conversation amongst people.

In other respect, viewed from the educational field, English as an international language become the first foreign language that taught in Indonesia as a compulsory subject. In this present time, the students have been introduced English language by the teacher since the level of kindergarten until college. It proves that learning English is really important to be learnt by the students. There are four basic skills that needed to be learnt in learning a language especially English, such as reading, writing, listening, and speaking. In the other hand, there are also some aspects that involved in learning English, such as structure, pronunciation, and vocabulary. 
In learning English as a foreign language, the term of vocabulary cannot be separated from the teaching learning process. Tozcu and Coady (2004) pointed out that learning vocabulary is an important aspect of the second language and foreign language acquisition and academic achievement and it is vital to reading comprehension and proficiency, to which it is closely linked. Vocabulary is a root for the four skills in learning English i.e.Listening, Speaking, Reading, and Writing. Willis (2008) in (Wilsana ,Marhum , \& Kamaruddin , 2015) tells when students can increase their mastery of vocabulary, it can be better in communicating ideas, knowledge and their opinions. Mastering English vocabulary might give a huge privilege for the students to build a better communication with their opponents in speaking, generate an idea in writing, and understand some one utterance when they are talking. Wilkinsin Thornbury (2002) states without grammar very little can be conveyed, without vocabulary nothing can be conveyed. It can be inferred that someone who lack of vocabulary, he will find hard to utter or produce something in both orally or written. Furthermore, Ur(1996) supported that vocabulary is one of important things to be taught in learning foreign language because it will be impossible to speak up without variety of words.

Unfortunately, in fact, there are still a number of students who find the difficult to communicate orally and generate some ideas in writing due to lack of vocabulary that they have. It does not mean that the students do not have any idea in their mind, yet, they confuse how to express it in oral and written communication. Rohmatillah (2014) stated that English vocabulary is different from Indonesian viewed from form, including pronunciation and spelling, meaning and the word use. In addition, the way of pronouncing the word is quite different from writing. Generally, it is presumed that High School students who learn English often find difficulties in learning vocabulary. This tends to be reason why the teacher has to find creative way in teaching in order to build the learning atmosphere become effective and enjoyable at the same time.

In line with the explanation above, there are a lot of techniques or methods that can be used by the teacher in order to help the students improve their vocabulary, one of which is by using video or audiovisual media. The term audio-visual media can be defined as the media that can be heard and seen simultaneously. The utilization of audio-visual media in teaching and learning process will help teachers to attain the objectives of a material which is being learnt. Further, it provides the easiness for the teachers to download various kinds of audio-visual media in the internet related to the material which will be learnt in the class. Furthermore, the use of audio-visual will make the learning atmosphere become more interesting and prevent the monotony during the learning process. Therefore, in this research, the use of audio-visual media is expected to be a way in improving students' vocabulary mastery.

Regarding the previous researchers concerning with the use of audio-visual media in teaching and learning process, Hartono (2013) was intended to see the significant difference between the vocabulary of students who were taught by using audio-visual media and those who were taught by not using it. The data that have been provided on that research showed that there are significant differences between those two classes. Further, the data proved that it was effective to use audio-visual media to increase students' vocabulary ability. 
Another research was conducted by Andriani(2016). That research was intended to find out whether Interactive Video Multimedia can better improve the students' vocabulary mastery, and to find out factors that influence it. The test, observation checklist, filed notes, and interview, those are the things that used in that research to gain the data. The finding showed that there is the improvement toward the students' vocabulary mastery. Another previous research was conducted by Himawanto (2015) which dealt with the effectiveness of using audio-visual media as media to teach vocabulary at the VII grades students. It showed that teaching vocabulary by using audio-visual media made the students enthusiastic.

In reference to the previous research above, it can be inferred that the use of audio-visual media in the teaching and learning process could better increase the students' vocabulary mastery. Hence, the researcher intended to conduct the research dealt with the utilization of audio-visual media to improve students' vocabulary mastery.However, there are some differences of the previous research and this research. In this research, the researcher uses an online platform 'WhatsApp' in order to share the media to the students, while the previous researcher played the media directly in the class. Further, either the level of the students or the subjects are not the same. On the other hand, the similarity of the research is almost the same that is to find out the improvement the students' vocabulary mastery after the implementation of audio-visual media.

\section{METHODS}

This research included in quantitative research. The main aim of this research was to find out whether there was a significant differenceof students' vocabulary achievement before and after the implementation of audio-visual media in the teaching and learning process. Hatch and Farhady (1982) stated that quantitative research is a kind of research in which the data tend to use statistic as a measurement in deciding the conclusion. This research was conducted based on experimental method where the researcher applied the pretest-posttest (T1 X T2). This design was intended to investigate the students' vocabulary achievement before and after conducting the research through the result of pretest-posttest.

The population of this research was the tenth grade students of Senior High School Muhammadiyah 2 Bandar Lampung. Meanwhile, the sample was narrowed of the population as the experimental class. Further, the researcher took one class out of the experimental class to be given the try-out of the instrument. Both of two classes were chosen by using random sampling technique. Moreover, in this research, the instruments that being chosen to gain the data were vocabulary test consist of pre-test and post-test. Further, the tests were based on the technique of assessing vocabulary. Pre-test was conducted in the first meeting before the treatment given in order to see the vocabulary achievement by the students. Moreover, post-test was administered by the time after the treatment applied in the class.

There were some research procedures in order to collect the data, those were recognizing the problem, determining the population and selecting the sample, administering try-out, administering the pre-test, conducting the treatment, administering the post-test, and analyzing the data. 
a.) Recognizing the Problem

In this research, the researcher used vocabulary that can be found in narrative text to improve students' vocabulary mastery. The researcher intended to find out whether or not there is significant differencetowards the students' vocabulary achievement.

b.) Determining the Population and Sample

The population of this research was the tenth grade students of Senior High School Muhammadiyah 2 Bandar Lampung. Meanwhile, in determining the sample in this research, the researcher used a random sampling which represents the population as the experimental class. Further, all the tenth grade students had the same opportunity in this research.

c.) Conducting Try-out

Try out test was conducted in order to find out whether both of vocabulary test items and the alternatives have already fulfilled the good quality of validity, reliability, level of difficulty, and discrimination power.

d.) Administering Pre-test

Pre-test was administered to see the students' vocabulary mastery before the treatment of audiovisual media given in the class. The students were given some questions with multiple choices. Further, the time was given to answer the question approximately 60 minutes.

e.) Giving Treatment

After giving the pre-test, the treatment of the use of audiovisual media was applied in the class. This treatment was conducted in three meetings in which the time for each meeting is $2 \times 45$ minutes.

f.) Administering Post-test

The post-test was administered after the treatment given to the students. This test aimed to measure the progress of the students' vocabulary achievement.

g.) Analyzing the Data

Both of pre-test and post-test in quantitative data was analyzed. In order to see whether there was significant difference towards the students' vocabulary mastery to the students before and after the treatment applied in the class, those data were analyzed by using SPSS.

After collecting the quantitative data, all the result of the pre-test and post-test of the students compared. The score of both of the data was computed by the researcher in order to find out whether or not there is significant difference towards the students' vocabulary mastery after the researcher using audiovisual media in the class. The researcher scored the answer of students' pre-test and post-test. After that, the researcher computed the mean score using formula which is designed by Arikunto (2006), and drew the conclusion by comparing the means of pretest and posttest.

$$
X=\frac{\sum \mathbf{x}}{N}
$$

This formula is described as follows:

$\begin{array}{ll}\mathrm{X} & \text { : mean score } \\ \sum \mathrm{x} & \text { : sum of individual score } \\ \mathrm{N} & \text { : number of students }\end{array}$ 


\section{RESULTS AND DISCUSSIONS}

\section{Results}

In order to investigate whether or not there was significant difference of students' vocabulary mastery after being taught by using audiovisual media through WhatsApp, the researcher administered the pre-test and post-test. The try-out test was administered first in order to analyze the reliability, level of difficulty, and discrimination power of the test in order to achieve good test instrument criteria. On the other hand, the pre-test and post-test were administered in the different class, so as to look into the difference of students' vocabulary mastery mainly in content words - noun, verb, adjective, and adverb, after being taught by using audiovisual media or video. The pre-test had been conducted in the first meeting at the experimental class. Besides, the post-test was administered in the last meeting of the research. As the result, the researcher found that there was a difference of students' score of pre-test and post-test. To made it more specific, it can be seen from the table below:

Table 1. The Difference of Students' Vocabulary Mastery

\begin{tabular}{|ccc|}
\hline Mean Score of Pre-test & Mean Score of Post-test & Gain \\
\hline 5.24 & 6.67 & 1.43 \\
\hline
\end{tabular}

From the table above, it shows the significant difference of students' vocabulary before and after the implementation of audiovisual media. The mean score of pre-test is gotten from the accumulation of the individual range score of pre-test divided by the total number of students who took the test. The data shows that the mean score of the pre-test is 5.24. Further, the formula of post-test has the same calculation as the pre-test. Yet, the mean score of students' post-test is 6.67 , which mean there is the difference of students' score before and after treatment. The different number of post-test and pre-test shows the number of 1.43 .

In order to analyze the difference of students' vocabulary mastery, the result of pre-test and post-test were compared. The final mean score of pre-test is gotten from the accumulation of the individual range score of pre-test divided by the total number of students who took the test. The data shows that the mean score of the pre-test is 5.24. Further, the formula of post-test has the same calculation as the pre-test. Yet, the mean score of students' post-test is 6.67, which mean there is the difference of students' score before and after treatment. The different number of post-test and pre-test shows the number of 1.43. The table below provides the results of the hypothesis of students' mean score of the tests.

Table 2. Paired Samples T-Test

Paired Samples Test

\begin{tabular}{|c|c|c|c|c|c|c|c|c|c|}
\hline & & \multicolumn{5}{|c|}{ Paired Differences } & \multirow{3}{*}{\multicolumn{2}{|c|}{$\mathrm{t} \quad \mathrm{df}$}} & \multirow{3}{*}{$\begin{array}{l}\text { Sig. (2- } \\
\text { tailed) }\end{array}$} \\
\hline & & \multirow[t]{2}{*}{ Mean } & \multirow[t]{2}{*}{$\begin{array}{c}\text { Std. } \\
\text { Deviation }\end{array}$} & \multirow[t]{2}{*}{$\begin{array}{l}\text { Std. Error } \\
\text { Mean }\end{array}$} & \multicolumn{2}{|c|}{$\begin{array}{c}\text { 95\% Confidence } \\
\text { Interval of the } \\
\text { Difference }\end{array}$} & & & \\
\hline & & & & & Lower & Upper & & & \\
\hline $\begin{array}{l}\text { Pair } \\
1\end{array}$ & $\begin{array}{l}\text { Post- } \\
\text { test - } \\
\text { Pre- } \\
\text { test }\end{array}$ & 1.42424 & 1.50063 & .26123 & .89214 & 1.95634 & 5.452 & 32 & .000 \\
\hline
\end{tabular}


From the calculation of the test table above, it can be seen that the value of two-tailed significant is 0.000 which can be inferred that it is lower than 0.05 . Thus, $\mathrm{H}_{0}$ is rejected that means $\mathrm{H}_{1}$ is accepted. Concerned to the data provided on the table above, it shows that there is significant difference of students' vocabulary mastery before and after the implementation of audiovisual media. It proves by the t-value shows the number of 5.452 which is higher than the t-table 2.0369, it can be seen that the students' achievement was increased since the data showed that the t-value $>\mathrm{t}$-table, that was $5.452>2.0369$. Reflected from the data above, it can be drawn to the conclusion that there is a significant difference of students' vocabulary mastery after the implementation of audiovisual media through WhatsApp. All in all, it also proves that it is effective to use audiovisual media to the $10^{\text {th }}$ grade students of SMA Muhammadiyah 2 Bandar Lampung.

Table 3. Improvement of Students' Vocabulary Mastery in Content Words

\begin{tabular}{|cccccc|}
\hline No & $\begin{array}{c}\text { Types of Content } \\
\text { Words }\end{array}$ & Mean of Pre-test & Mean of Post-test & Gain & Percentage \\
\hline 1 & Noun & 29.46 & 31.00 & 1.54 & $20.37 \%$ \\
\hline 2 & Verb & 27.38 & 30.15 & 2.77 & $36.64 \%$ \\
\hline 3 & Adjective & 30.58 & 31.83 & 1.25 & $16.53 \%$ \\
\hline 4 & Adverb & 28.33 & 30.33 & 2.00 & $26.46 \%$ \\
\hline & Total & $\mathbf{1 1 5 . 7 5}$ & $\mathbf{1 2 3 . 3 1}$ & $\mathbf{7 . 5 6}$ & $\mathbf{1 0 0 \%}$ \\
\hline
\end{tabular}

It proves from the table 4.6 that there is an improvement of students' vocabulary mastery in each type of content words after three times of the implementation of audiovisual media in teaching vocabulary through WhatsApp. It proves by the mean of pre-test is (115.75), meanwhile the average score of post-test is (123.31). It can be inferred that the gain score of students' vocabulary is (7.56) with the total percentage of $100 \%$.

\section{Discussions}

After gathering and calculating the data of the research, the researcher found the answer for this research question that was "Is there a significant difference to the students' vocabulary mastery before and after the implementation of audio-visual media?" Generally, the researcher found that teaching vocabulary by using audiovisual media through WhatsApp was able to give a significant difference to the students' vocabulary mastery. It was proved by the result from the gain of the pretest and post-test score. In accordance to that, the data showed that the mean score for the pre-test is 5.24 and the mean score for the post-test is 6.67. It means that the improvement of students' vocabulary achievement reaches out the score of 1.43 points.

In this research, there were two classes used by the researcher, the first class was X MIPA 3 as try-out class. Meanwhile, another class was X MIPA 1 used by the researcher as the sample of this research. There were two kinds of test used in this research, that were the pre-test and posttest. The researcher administered the pre-test in order to know the achievement of students' vocabulary mastery before conducting the research. Viewed from the result of the pre-test, the researcher found that the highest raw score of the pre-test is 48.67 , in the other side, the lowest score is 24.67 . This is caused because the students were still had a low vocabulary mastery in each of type of content words - noun, verb, adjective, and adverb. Therefore, the researcher conducted the treatment in the experimental class. 
The researcher shared the audiovisual media, the material and some worksheets which were in line with the students' capacities. Moreover, the researcher used audiovisual media and sent the video through WhatsApp. Further, narrative text used in this research during three times treatment in the experimental class. During the treatment, the students were felt excited to download the video given, and answer to the questions based on the video given by the researcher.In the other side, the post test was held in the last meeting in order to collect the data after the treatment of the research. The students' achievement of post-test' score improved from the score of pre-test. It proves by the highest score from the raw score is 50, in the other side, the lowest score is 39.33. In order to investigate the students' achievement before and after the treatment was given, the researcher compared both of the students' score. As a result, the t-value is higher than the t-table which means that the hypothesis proposed by the researcher is accepted.

In line with the statement before, it was supported by the previous research which also concerned with the use of audio-visual media in teaching and learning process, Hartono (2013) found that there are significant differences between those two classes. Further, the data proved that it was effective to use audio-visual media to increase students' vocabulary ability. Another research was conducted by Andriani(2016) which the findings showed that there is the improvement toward the students' vocabulary mastery. And for another previous research was conducted by Himawanto (2015) proved that teaching vocabulary by using audio-visual media made the students enthusiastic. Undoubtedly, the researcher summed up that the implementation of audiovisual media was effective and made the students' enthusiastic in learning vocabulary.

In composing the data of pre-test and post-test, the researcher used content words of vocabulary. The mean score of noun for the pre-test is 29.46 which lower than the students' achievement of post-test that is 31.00 . Besides, in terms of verb, the students only get 27.38 points as the mean score for pre-test, meanwhile on the post-test that is 30.15. Further, concerning to the adjective used in the test, the students' get 30.58.; mean score for adjective in pre-test and increase to 31.83 in post-test. Likewise, adverb also has an improvement from the mean 28.33 for the posttest and 30.33 for the mean of post-test. At the end of the research, the researcher analyzed the data by using SPSS 20 for Windows.

For the final analysis, the researcher found that the implementation of audiovisual media in teaching vocabulary could give the positive impact to the students. It improved the students' vocabulary mastery in terms of content words. The students were very excited in learning English with the video provided as one of the learning material. To conclude, it could be approved that the implementation of audiovisual media through WhatsApp was an effective technique to teach vocabulary at the tenth grade of SMA Muhammadiyah 2 Bandar Lampung.

\section{CONCLUSIONS AND SUGGESTIONS}

\section{Conclusions}

After accomplishing the research and analyzing the data, the researcher draws the conclusion that in general, the use of audiovisual media or video in the teaching and learning process can give significant difference to the students' vocabulary mastery. Referred to the result of the research, there is a significant difference of students' vocabulary mastery after the use of audiovisual media or video. It was proved from the data that showed the students' mean score in the posttest was higher than pretest. 


\section{Suggestions}

Since the data showed that there was a significant difference of students' vocabulary mastery after the usage of audiovisual media or video, the researcher suggested the English teacher to have the same technique as the researcher in teaching vocabulary. Referring to the advantages by using audiovisual media, this technique can be considered as the attractive and effective way that can be applied in the learning process. Its usage was able to boost students' motivation up in learning new vocabulary and identify its categorization into noun, verb, adjective, or adverb. However, the teacher needs to manage the time properly. Since this usage of audiovisual media require some minutes for the students to look for the video given.

Besides, this research also had some limitations. First of all, this research was conducted in the tenth grade students of Senior High School. Thus, the different levels of students in Senior High School, Junior High School or University are suggested to be chosen as the sample for further researcherin order to find out the result of students' achievement by using audiovisual media in the different level of grade. Second, the researcher used narrative text as the material during the treatment in the class. In order to investigate the students' achievement by using audiovisual media for the other kind of text, the researcher suggests for further researcher to use different text in using audiovisual media beside narrative text. Last, during the research, the researcher used an online platform that was WhatsApp to improve the students' vocabulary mastery. Thus, the researcher hopes that for the next researcher can improve English components such as pronunciation or even English skills - speaking, listening, reading, and writing.

\section{References}

Andriani, R. (2016). Improving students' vocabulary mastery using interactive multimedia. ELT-Lectura, 3(1).

Hartono, R. (2013). The use of audiovisual media to increase the students' vocabulary: a case of the tenth grade students of SMAN 1 Cepiring Kendal. ETERNAL (English Teaching Journal), 4(1).

Hatch, E., \&Farhady, H. (1982). Research design and statistics for applied linguistics. New York: Newbury House.

Himawanto, F. R. (2015). The effectiveness of teaching vocabulary by using audiovisual as media toward vocabulary mastery of the VII C grade students of SMPN 3 KedungwaruTulungagung in academic year 2014/2015 (Undergraduate thesis, IAIN Tulungagung).

Rohmatillah, R. (2014). A study on students' difficulties in learning vocabulary. English Education: JurnalTadris Bahasa Inggris, 6(1), 75-93.

Thornbury, S. (2002). How to teach vocabulary. London: Longman

Tozcu, A., \&Coady, J. (2004). Successful learning of frequent vocabulary through CALL also benefits reading comprehension and speed. Computer assisted language learning, 17(5), 473-495.

Ur, P. (1996). A course in language teaching: practice and theory. Stuttgart: Ernst KlettSprachen.

Wilsana, A., Marhum, M., \&Kamaruddin, A. (2015). Teaching vocabulary to grade VIII students at SMPNegeri 9 Palu by using word wall strategy. Bahasantodea, 3(2). 